\title{
Disease Susceptibility of Interspecific Cold-Hardy Grape Cultivars in Northeastern U.S.A
}

\author{
Ann L. Hazelrigg ${ }^{1}$, Terence L. Bradshaw ${ }^{2, *(D)}$ and Gabriella S. Maia ${ }^{1}$ \\ 1 University of Vermont Extension, 63 Carrigan Dr, Burlington, VT 05405, USA; \\ ann.hazelrigg@uvm.edu (A.L.H.); gabriella.silveira-maia@uvm.edu (G.S.M.) \\ 2 Department of Plant \& Soil Science, University of Vermont, 63 Carrigan Dr, Burlington, VT 05405, USA \\ * Correspondence: terence.bradshaw@uvm.edu
}

Citation: Hazelrigg, A.L..; Bradshaw,

T.L..; Maia, G.S.. Disease

Susceptibility of Interspecific

Cold-Hardy Grape Cultivars in

Northeastern U.S.A. Horticulturae

2021, 7, 216. https://doi.org/

10.3390/horticulturae7080216

Academic Editor: Harlene

Hatterman-Valenti

Received: 1 June 2021

Accepted: 28 July 2021

Published: 30 July 2021

Publisher's Note: MDPI stays neutral with regard to jurisdictional claims in published maps and institutional affiliations.

\begin{abstract}
Susceptibility to diseases of economically important grapes is critical to the evaluation of germplasm recommended for commercial production and for the development of sustainable production systems. In 2018-2019, the cold-hardy grape cultivars including 'Brianna', 'Crimson Pearl', 'Itasca', 'Louise Swenson', 'Marechal Foch', 'Marquette' ‘Petite Pearl', 'St. Pepin', and 'Verona' were evaluated on non-treated vines for susceptibility to downy mildew, powdery mildew, black rot, anthracnose, Phomopsis leaf spot and fruit rot, and Botrytis bunch rot. No cultivars were consistently disease-free, and all exhibited some degree of black rot and powdery mildew infection. Relative susceptibility to disease was not consistent across both years, but 'Brianna' had greater incidence of black rot and 'Louise Swenson' showed lower incidence of powdery mildew in both years. The relatively new cultivars 'Crimson Pearl' and 'Verona' exhibited comparatively moderate disease susceptibility overall. Growers typically manage diseases with fungicides on commercial farms, so cultivar susceptibility is just one component of a sustainable pest management and production system.
\end{abstract}

Keywords: Vitis spp.; interspecific hybrid grapes; cultivar evaluation; Integrated Pest Management; disease resistance

\section{Introduction}

Winegrapes are an emerging and expanding crop throughout the New England states in the northeastern U.S.A. and the recent introduction of several new cold-tolerant cultivars now allows production in regions where low winter temperatures previously precluded cultivation [1]. According to a 2014 NASS report where grapes were singled out as a crop for the first time in New England, there were 360 ha of grapes grown in New England, yielding an average of 5.6 MT.ha ${ }^{-1}$ [2]. The value of the utilized production for the area was $\$ 4,200,000$, resulting in an average of $\$ 11,600$ per ha. This figure does not take into consideration any of the value-added income potential of turning these grapes into wine. Vermont land area devoted to grape production doubled from 2007 to 2012 [3] and increased again by $34 \%$ by 2017 [4].

Grape production requires a long period of at least 3-4 years from planting until attaining any substantial marketable production, and high establishment costs of about US\$20,000 per hectare exclusive of land costs makes production capital-intensive and risky in the short term [5]. Most vineyards in Vermont are managed using Integrated Pest Management (IPM) methods, but an increasing number of vineyards have adopted 'natural' production methods that include practices used in organic and biodynamic production systems [6]. In a 2016 survey of grape producers from Vermont and surrounding states, disease management was ranked among the greatest threats to their operations [1].

In both IPM and 'natural' production systems, cultivar resistance to disease is a critically important component of sustainable fruit production. Because grape production is relatively new in the region and made possible only by recently bred cultivars, continued breeding and germplasm evaluation has contributed to turnover in recommended 
and planted cultivars. Public coordinated evaluation programs including NE-1020/1720 Multistate Evaluation of Winegrape Cultivars and Clones [7-11] and Northern Grapes Project [12] have assisted the relatively rapid collection and dissemination of performance metrics for new winegrape cultivars. The research presented in this paper is a product of that effort.

Grapes can be difficult to grow in the humid northeast and the complex of fungal diseases that attack foliage and fruit clusters is particularly challenging. Diseases in Vermont vineyards can include black rot (Phyllosticta ampelicida, teleomorph Guignardia bidwellii), Phomopsis leaf spot and fruit rot (P. viticola), powdery mildew (Erysiphe necator), downy mildew (Plasmopara viticola), anthracnose (Elsinoe ampelina), and Botrytis (B. cinerea) bunch rot and blight among others. In slightly warmer regions of the central and eastern Northern United States, such as Finger Lakes, New York; Niagra Peninsula, Ontario; and portions of Michigan and other states with favorable proximity to the Great Lakes, relatively cold-hardy $V$. vinifera grape cultivars of Eurasian origin, such as 'Riesling' and 'Cabernet Franc', are grown among other, more cold-hardy hybrid and North Americannative cultivars with lower risk for crop loss from cold damage [13]. In those regions where cold-hardy $V$. vinifera and interspecific hybrids are grown in proximity to one another, the relative disease resistance of the hybrids is apparent, as growers typically apply 8-12 fungicide sprays annually for the former compared to 5-6 for the latter [14].

In addition to selection for cold hardiness, the recent inter-specific grape cultivars have also been bred for disease resistance. The majority of cultivars grown in the colder regions of the upper Midwest and Northern U.S., where V. vinifera production is unreliable, were developed in three breeding programs located in Minnesota or adjacent Wisconsin. Each of these breeding programs has used $V$. vinifera, included for its juice quality for winemaking, and native North American species, particularly $V$. labrusca and V. riparia, which impart cold hardiness to the crosses $[15,16]$. Because the North American species co-evolved with disease-causing organisms native to the region, and $V$. vinifera co-evolved with many plant pathogens originating in Eurasia, these interspecific hybrids tend to have lower overall disease susceptibility than more commonly grown commercial cultivars.

In 2007-2015, six interspecific winegrape cultivars were evaluated in South Burlington, VT, USA (lat. 44.43162, long. -73.20186) for horticultural and juice quality characteristics [9]. In addition to those cultivars, 'Traminette' and 'Vignoles' were removed from the planting before complete evaluation was completed for exhibiting poor cold hardiness and crop yield and are not grown commercially in Vermont. A recent industry survey indicated that 'Corot Noir' has never been commercially planted in Vermont, 'Prairie Star' is planted on very little land area, and 'Frontenac' is being removed by commercial growers in favor of cultivars exhibiting enhanced wine quality [1]. Since winegrape production is so new in the region, older cultivars continue to be considered for suitability to the regions' soil and climate, and new cultivars continue to be released, comprehensive evaluation of horticultural, juice quality, and pest susceptibility is necessary to reduce risk in planting and managing this long-term, perennial crop.

This long-term study includes a comprehensive evaluation of new and newly evaluated older winegrape cultivars for suitability of production in Vermont and similar cold-climate regions. Parameters of interest in the five- to ten-year evaluation include cold hardiness, vine growth, crop yield, and juice quality. However, disease susceptibility is also an important determinant of cultivar suitability, particularly in the humid northeastern U.S.A. Disease susceptibility must ultimately be measured under non-sprayed conditions, which would compromise horticultural and juice quality evaluation in later years. Therefore, this preliminary study was conducted over two years in the early life of the vineyard as fruit production was just beginning. We hypothesize that winegrape cultivars will exhibit differences in incidence and severity of commercially-important diseases under non-sprayed conditions. This knowledge will guide development of sustainable disease management programs for emerging winegrape cultivars in the region. 


\section{Materials and Methods}

\subsection{Research Site}

The research vineyard was planted in 2016 at the University of Vermont Horticulture Research Center in South Burlington, VT, U.S.A. (USDA hardiness zone 5a, Köppen-Geiger classification Dfb) located in the Lake Champlain valley. The soil type is a well-drained Adams Windsor loamy sand (USDA NRCS, 2016) with $\mathrm{pH}$ 7.2. The nine own-rooted cultivars were planted following USDA NE-1720: Multi-state Coordinated Evaluation of Winegrape Cultivars and Clones trial protocols [11]. In this project, research personnel from multiple U.S. states annually convene to coordinate research protocols and share results to increase project reach. This study is the first published under the protocols adopted by the group in 2017.

Vines of the cultivars 'Crimson Pearl', 'Itasca', 'Petite Pearl', 'St. Pepin', and 'Verona' were planted in a randomized complete block design of six blocks with two-vine plots of each cultivar per block at $1.8 \mathrm{~m}$ between vines and $3.0 \mathrm{~m}$ between rows. In addition, vines of 'Brianna', 'Louise Swenson', 'Marechal Foch', and 'Marquette' were planted in solid rows at the same spacing in rows immediately adjacent to the mixed rows of other cultivars (Table 1). Similar proximity within the vineyard, vine age, and management practices applied to both the randomized NE-1720 section and the adjacent vines were considered when including all cultivars in the same trial for the purpose of this study.

Table 1. Breeding program origination for nine winegrape cultivars evaluated in South Burlington, VT, USA.

\begin{tabular}{cccc}
\hline Cultivar & Wine Color & Year Released & Breeding Program $^{\mathbf{1}}$ \\
\hline Brianna & White & 2001 & Swenson \\
Crimson Pearl & Red & 2015 & Plocher \\
Itasca & White & 2017 & UMN \\
Louise Swenson & White & 2001 & Swenson \\
Marechal Foch & Red & $1951^{2}$ & Kuhlmann \\
Marquette & Red & 2006 & UMN \\
Petite Pearl & Red & 2009 & Plocher \\
St. Pepin & White & 1986 & Swenson \\
Verona & Red & 2015 & Plocher \\
\hline
\end{tabular}

${ }^{1}$ Kuhlmann = private breeder Eugène Kuhlmannin, Alsace, France; Plocher = private breeder Tom Plocher, Hugo, MN, U.S.A.; Swenson = private breeder Elemer Swenson, Osceola, WI, U.S.A.; UMN = University of Minnesota, Chanhassen, MN, U.S.A. ${ }^{2}$ Release year in USA.

Vines were trained from two trunks per vine to a $1.8 \mathrm{~m}$ high-wire dual unilateral cordon spur-pruned system. Drip irrigation was applied when soil water potential was below $25 \mathrm{kPa}$ based on soil tensiometer readings. The vineyard received mineral nutrients as determined by soil and petiole nutrient analysis, and weekly vineyard scouting $[17,18]$. The research vineyard was located immediately adjacent to a previous planting in which disease presence has been recorded [19], and within $50 \mathrm{~m}$ of wild, unmanaged grape vines that grew in an adjacent tree canopy and typically showed some level of disease. Therefore, we assumed that disease inoculum is sufficiently present to evaluate new vines for diseases commonly found in area vineyards. No fungicide or insecticide treatments were applied in 2018 or 2019 in order to evaluate natural cultivar susceptibility to disease.

\subsubsection{Foliage Assessment}

Foliar incidence (presence/absence) and severity (area infected) assessments were performed annually and included: downy mildew, powdery mildew, black rot, Phomopsis leaf spot, and anthracnose. For cultivars 'Brianna', 'Louise Swenson', 'Marquette', and 'Marechal Foch', the center two vines in a four-vine panel were sampled. For cultivars 'Crimson Pearl', 'Itasca', 'Petite Pearl', 'St. Pepin', and 'Verona', both vines of the two-vine panel were sampled. Six two-vine replications were assigned per cultivar. 
Twenty-five leaves were randomly selected for disease assessment from each two-vine panel on 27 August 2018 and 4 September 2019 cultivar. Foliage samples were held in plastic bags at $2.2^{\circ} \mathrm{C}$ until examined in the laboratory. Foliar disease incidence and severity were determined by visually assessing both surfaces of 20 leaves randomly selected from each two-vine panel per cultivar. A dissecting microscope was used for further examination if needed. Each leaf was assessed for the incidence and severity of the following diseases: downy mildew, powdery mildew, black rot, anthracnose, and Phomopsis leaf spot. Diseases were identified using standard diagnostic tools and protocols $[20,21]$.

\subsubsection{Fruit Cluster Assessment}

Fruit clusters from each cultivar replicate were collected annually for evaluation prior to harvest on 12 September 2018 and between 23 September and 14 October 2019, depending on the cultivar. 'Marquette' fruit cluster samples were not collected in 2019. Clusters were held in plastic bags at $2.2{ }^{\circ} \mathrm{C}$ until examined. Fruit disease incidence and severity were determined by visually assessing ten randomly selected clusters for each cultivar. A dissecting microscope was used for further examination if needed. Each cluster was assessed for the incidence and severity of the following diseases: downy mildew, powdery mildew, black rot, Phomopsis fruit rot, Botrytis bunch rot, and anthracnose. The Horsfall-Barratt scale (Table S1) was used to rate disease severity on foliage and clusters. If a specific disease was present, the end-point of the Horsfall-Barratt disease range (e.g., 3, 6, 12,25 , etc.) was recorded on the data sheet to indicate the area affected [22].

\subsubsection{Statistical Analysis}

Data were analyzed separately by year with cultivar as the treatment variable. An analysis of variance (PROC GLM) was completed using SAS 9.4 software (SAS, Inc., Cary, $\mathrm{NC}$, USA). If the overall effect from treatment was significant at $\alpha=0.05$, Tukey's Honest Significant Difference (HSD) test was used to make pairwise comparisons of effects by cultivar at overall $\alpha=0.05$.

\section{Results}

No downy mildew was observed on fruit or foliage and no anthracnose observed on fruit during the study, and those data are not further presented.

\subsection{Foliage Assessment}

In 2018, incidence of powdery mildew ranged from $22.5 \%$ to $95.0 \%$ (Table 2). 'Marquette' had greatest incidence of the disease which was greater than all other cultivars except 'St. Pepin' and 'Verona'. 'Itasca', 'Brianna', and 'Louise Swenson' had the lowest incidence of powdery mildew in that year. However, in 2019, 'Marquette' and 'Louise Swenson' both had $100 \%$ incidence of powdery mildew on leaves, followed by 'Brianna', 'Petite Pearl', 'St. Pepin', and 'Verona', which had 75.8-89.2\% incidence. Foliage infected with powdery mildew was the lowest (22.5\%) in 'Louise Swenson' in 2018, yet in 2019, this same cultivar had the highest incidence (100\%). 'Marechal Foch' had 50\% incidence and 'Itasca' had the lowest incidence, with only $22.5 \%$ of leaves affected. Disease severity trends generally followed incidence and were not consistent between the years for some cultivars. In particular, disease severity on 'Louise Swenson' was lowest in 2018, but among the highest in 2019, and a similar pattern was observed for 'Marechal Foch'.

Black rot on foliage (Table 3) varied between the years, and some trends were apparent. 'Brianna' had among the highest incidence of foliar black rot in both years, and in 2019, the incidence of disease on that cultivar, with $83.3 \%$ of leaves affected, was substantially greater than the other cultivars, which had an incidence of $0.8-28.3 \%$ of foliage with the disease. 'Itasca', 'Marquette', and 'Verona' had a similar incidence of black rot to 'Brianna' in 2018 (range 13.3-18.3\%). 'Marechal Foch' and 'Louise Swenson' had among the lowest levels of incidence and severity of foliar black rot in both years. 
Table 2. Comparison of the incidence percentage and severity of powdery mildew symptoms on grape foliage and clusters in 2018 and 2019.

\begin{tabular}{|c|c|c|c|c|c|c|c|c|c|c|c|c|c|c|}
\hline \multirow{4}{*}{ Cultivars } & \multicolumn{14}{|c|}{ Powdery Mildew $^{1}$} \\
\hline & \multicolumn{7}{|c|}{2018} & \multicolumn{7}{|c|}{2019} \\
\hline & \multicolumn{4}{|c|}{ Foliage } & \multicolumn{3}{|c|}{ Cluster } & \multicolumn{4}{|c|}{ Foliage } & \multicolumn{3}{|c|}{ Cluster } \\
\hline & \multicolumn{2}{|c|}{$\%$ Inc. $^{2}$} & \multicolumn{2}{|c|}{$\%$ Sev. $^{2}$} & \multirow{2}{*}{$\begin{array}{c}\text { \% Inc. } \\
88.33 \\
\end{array}$} & \multicolumn{2}{|c|}{$\%$ Sev. } & \multicolumn{2}{|c|}{$\%$ Inc. } & \multicolumn{2}{|c|}{$\%$ Sev. } & \multirow{2}{*}{$\begin{array}{l}\% \text { Inc. } \\
100.00\end{array}$} & \multicolumn{2}{|c|}{$\%$ Sev. } \\
\hline Brianna & 35.83 & de & 1.54 & bcd & & 20.51 & $\mathrm{a}$ & 75.83 & $\mathrm{ab}$ & 4.93 & $\mathrm{bc}$ & & 14.26 & bcd \\
\hline C. Pearl & 51.67 & cde & 2.00 & bcd & 70.00 & 3.08 & $\mathrm{~b}$ & 41.67 & $\mathrm{bc}$ & 1.85 & $\mathrm{c}$ & 100.00 & 17.18 & bcd \\
\hline Marechal Foch & 59.17 & bcd & 1.85 & bcd & 56.67 & 2.26 & $\mathrm{~b}$ & 50.00 & $\mathrm{bc}$ & 17.60 & $a b c$ & 100.00 & 11.48 & $\mathrm{~cd}$ \\
\hline Itasca & 38.33 & de & 0.98 & $\mathrm{~cd}$ & 95.00 & 8.55 & $a b$ & 22.50 & c & 0.53 & c & 100.00 & 6.21 & $\mathrm{~d}$ \\
\hline L. Swenson & 22.50 & $\mathrm{e}$ & 0.55 & $\mathrm{~d}$ & 63.33 & 2.65 & $\mathrm{~b}$ & 100.00 & $\mathrm{a}$ & 21.91 & $a b$ & 100.00 & 24.67 & $a b$ \\
\hline Marquette & 95.00 & a & 3.22 & $a b$ & 86.67 & 7.03 & $\mathrm{~b}$ & 100.00 & $\mathrm{a}$ & 34.17 & $\mathrm{a}$ & - & - & \\
\hline Petite Pearl & 74.17 & $\mathrm{bc}$ & 1.87 & bcd & 100.00 & 3.24 & $\mathrm{~b}$ & 86.67 & $a b$ & 2.48 & c & 100.00 & 19.63 & $a b c$ \\
\hline St. Pepin & 80.83 & $\mathrm{ab}$ & 5.05 & $\mathrm{a}$ & 85.00 & 9.02 & $a b$ & 75.83 & $a b$ & 13.03 & $\mathrm{bc}$ & 100.00 & 34.63 & $\mathrm{a}$ \\
\hline Verona & 76.67 & $a b$ & 2.24 & $\mathrm{bc}$ & 60.00 & 7.58 & $\mathrm{~b}$ & 89.17 & $a b$ & 4.82 & bc & 100.00 & 17.16 & bcd \\
\hline
\end{tabular}

${ }^{1}$ Values represent the mean from six replicate, two-vine plots per cultivar of disease incidence on 20 leaves or 10 clusters per plot. Disease severity (area infected) was rated using the Horsfall-Barratt scale and converted to percentages using Elanco's conversion tables. Means followed by the same letters within columns are not significantly different according to Tukey's Honest Significant Difference (HSD) Test $(p \leq 0.05) .{ }^{2}$ Inc. = Incidence; Sev. = Severity.

Table 3. Comparison of the incidence percentage and severity of black rot symptoms on grape foliage and clusters in 2018 and 2019.

\begin{tabular}{|c|c|c|c|c|c|c|c|c|c|c|c|c|c|c|c|c|}
\hline \multirow{4}{*}{ Cultivars } & \multicolumn{16}{|c|}{ Black Rot ${ }^{1}$} \\
\hline & \multicolumn{8}{|c|}{2018} & \multicolumn{8}{|c|}{2019} \\
\hline & \multicolumn{4}{|c|}{ Foliage } & \multicolumn{4}{|c|}{ Cluster } & \multicolumn{4}{|c|}{ Foliage } & \multicolumn{4}{|c|}{ Cluster } \\
\hline & \multicolumn{2}{|c|}{$\%$ Inc. $^{2}$} & \multicolumn{2}{|c|}{$\%$ Sev. $^{2}$} & \multicolumn{2}{|c|}{$\%$ Inc. } & \multicolumn{2}{|c|}{$\%$ Sev. } & \multicolumn{2}{|c|}{$\%$ Inc. } & \multicolumn{2}{|c|}{$\%$ Sev. } & \multicolumn{2}{|c|}{$\%$ Inc. } & \multicolumn{2}{|c|}{$\%$ Sev. } \\
\hline Brianna & 16.67 & $\mathrm{ab}$ & 0.39 & $\mathrm{a}$ & 73.33 & $\mathrm{ab}$ & 3.16 & $\mathrm{~b}$ & 83.33 & a & 2.71 & a & 98.33 & $\mathrm{a}$ & 5.50 & $\mathrm{~cd}$ \\
\hline C. Pearl & 0.00 & $\mathrm{~b}$ & 0.00 & $\mathrm{~b}$ & 11.67 & $\mathrm{~d}$ & 0.27 & $\mathrm{~cd}$ & 28.33 & $\mathrm{~b}$ & 0.66 & $\mathrm{~b}$ & 94.44 & $\mathrm{a}$ & 3.42 & $\mathrm{~d}$ \\
\hline Marechal Foch & 0.00 & $\mathrm{~b}$ & 0.00 & $\mathrm{~b}$ & 16.67 & $\mathrm{~cd}$ & 0.43 & $\mathrm{~cd}$ & 0.83 & $\mathrm{e}$ & 0.02 & $\mathrm{e}$ & 100.00 & $\mathrm{a}$ & 48.39 & $\mathrm{a}$ \\
\hline Itasca & 15.00 & $\mathrm{a}$ & 0.35 & $\mathrm{a}$ & 30.00 & bcd & 0.82 & bcd & 12.50 & bcd & 0.29 & bcd & 100.00 & $\mathrm{a}$ & 11.91 & $\mathrm{C}$ \\
\hline L. Swenson & 2.50 & $a b$ & 0.06 & $a b$ & 3.33 & $\mathrm{~d}$ & 0.08 & $\mathrm{~cd}$ & 2.50 & de & 0.06 & de & 69.07 & $\mathrm{~b}$ & 2.17 & $\mathrm{~d}$ \\
\hline Marquette & 18.33 & $\mathrm{a}$ & 0.43 & $\mathrm{a}$ & 85.00 & a & 9.02 & $\mathrm{a}$ & 8.33 & cde & 0.23 & bcde & - & & & - \\
\hline Petite Pearl & 2.50 & $\mathrm{ab}$ & 0.06 & $a b$ & 48.33 & $\mathrm{bc}$ & 1.44 & $\mathrm{bc}$ & 6.67 & cde & 0.16 & cde & 98.33 & $\mathrm{a}$ & 3.24 & $\mathrm{~d}$ \\
\hline St. Pepin & 0.00 & $\mathrm{~b}$ & 0.00 & $\mathrm{~b}$ & 20.00 & bcd & 0.47 & $\mathrm{~cd}$ & 15.83 & $\mathrm{bc}$ & 0.37 & $\mathrm{bc}$ & 100.00 & $\mathrm{a}$ & 26.25 & $\mathrm{~b}$ \\
\hline Verona & 13.33 & $\mathrm{ab}$ & 0.31 & $a b$ & 1.67 & $\mathrm{~d}$ & 0.04 & $\mathrm{~d}$ & 19.17 & $\mathrm{bc}$ & 0.51 & $\mathrm{bc}$ & 100.00 & a & 34.09 & $\mathrm{~b}$ \\
\hline
\end{tabular}

${ }^{1}$ Values represent the mean from six replicate, two-vine plots per cultivar of disease incidence on 20 leaves or 10 clusters per plot. Disease severity (area infected) was rated using the Horsfall-Barratt scale and converted to percentages using Elanco's conversion tables. Means followed by the same letters within columns are not significantly different according to Tukey's Honest Significant Difference (HSD) Test $(p \leq 0.05) .{ }^{2}$ Inc. = Incidence; Sev. = Severity.

Phomopsis and anthracnose symptoms on foliage (Table 4) were not common in either year of the study, with a few exceptions. In 2018, Phomopsis was only observed on 'Verona', with $1.7 \%$ of leaves being affected and only $0.04 \%$ severity; in 2019, no Phomopsis was observed on that cultivar, but $20 \%$ of 'Brianna' and $8.3 \%$ of 'Marechal Foch' foliage had incidence of the disease, and severity was very low for both. No anthracnose was observed on any foliage in 2018, but in 2019, $45 \%$ of the assessed 'Brianna' foliage had anthracnose symptoms, and no other cultivars had the disease.

\subsection{Fruit Cluster Assessment}

Powdery mildew incidence (Table 2) was high on fruit in both years. In 2018, the incidence was $56.7-100 \%$ with no statistical separation among cultivars. In 2019, all assessed cultivars had $100 \%$ incidence of the disease on fruit. Severity was different among cultivars, and 'Brianna' had the greatest severity, while 'Crimson Pearl', 'Marechal Foch', 'Louise Swenson', 'Marquette', 'Petite Pearl', and 'Verona' had among the lowest severity of powdery mildew on fruit. As with foliar powdery mildew severity, that trend did not continue in 2019, when 'St. Pepin', 'Louise Swenson', and 'Petite Pearl' had among the highest severity of the disease. 
Table 4. Comparison of the incidence percentage and severity of Phomopsis and Anthracnose symptoms on grape foliage in 2018 and 2019.

\begin{tabular}{|c|c|c|c|c|c|c|c|c|c|c|c|c|}
\hline \multirow{3}{*}{ Cultivars } & \multicolumn{6}{|c|}{ Phomopsis $^{1}$} & \multicolumn{6}{|c|}{ Anthracnose ${ }^{1}$} \\
\hline & \multicolumn{2}{|c|}{2018} & \multicolumn{4}{|c|}{2019} & \multicolumn{2}{|c|}{2018} & \multicolumn{4}{|c|}{2019} \\
\hline & \multirow{2}{*}{$\frac{\% \text { Inc. }^{2}}{0.00}$} & \multirow{2}{*}{$\frac{{ }^{\%} \text { Sev. }^{2}}{0.00}$} & \multicolumn{2}{|c|}{$\%$ Inc. } & \multicolumn{2}{|c|}{$\%$ Sev. } & \multirow{2}{*}{$\begin{array}{c}\% \\
\text { Inc. } \\
0.00\end{array}$} & \multirow{2}{*}{$\begin{array}{c}\begin{array}{c}\% \\
\text { Sev. }\end{array} \\
0.00\end{array}$} & \multicolumn{2}{|c|}{$\%$ Inc. } & \multicolumn{2}{|c|}{$\%$ Sev. } \\
\hline Brianna & & & 20.00 & $\mathrm{a}$ & 0.59 & a & & & 45.00 & $\mathrm{a}$ & 3.06 & $\mathrm{a}$ \\
\hline C. Pearl & 0.00 & 0.00 & 0.00 & $\mathrm{~b}$ & 0.00 & $b$ & 0.00 & 0.00 & 0.00 & $\mathrm{~b}$ & 0.00 & $\mathrm{~b}$ \\
\hline Marechal Foch & 0.00 & 0.00 & 8.33 & $a b$ & 0.31 & a & 0.00 & 0.00 & 0.00 & $\mathrm{~b}$ & 0.00 & $\mathrm{~b}$ \\
\hline Itasca & 0.00 & 0.00 & 0.00 & $\mathrm{~b}$ & 0.00 & $\mathrm{~b}$ & 0.00 & 0.00 & 0.00 & $\mathrm{~b}$ & 0.00 & $\mathrm{~b}$ \\
\hline L. Swenson & 0.00 & 0.00 & 0.00 & $\mathrm{~b}$ & 0.00 & $\mathrm{~b}$ & 0.00 & 0.00 & 0.00 & $\mathrm{~b}$ & 0.00 & $\mathrm{~b}$ \\
\hline Marquette & 0.00 & 0.00 & 0.00 & $\mathrm{~b}$ & 0.00 & $b$ & 0.00 & 0.00 & 0.00 & $\mathrm{~b}$ & 0.00 & $\mathrm{~b}$ \\
\hline Petite Pearl & 0.00 & 0.00 & 0.00 & $\mathrm{~b}$ & 0.00 & $b$ & 0.00 & 0.00 & 0.00 & $\mathrm{~b}$ & 0.00 & $\mathrm{~b}$ \\
\hline St. Pepin & 0.00 & 0.00 & 0.00 & $\mathrm{~b}$ & 0.00 & $b$ & 0.00 & 0.00 & 0.00 & $\mathrm{~b}$ & 0.00 & b \\
\hline Verona & 1.67 & 0.04 & 0.00 & $b$ & 0.00 & $b$ & 0.00 & 0.00 & 0.00 & $\mathrm{~b}$ & 0.00 & b \\
\hline
\end{tabular}

${ }^{1}$ Values represent the mean from six replicate two-vine plots per cultivar of disease incidence on 20 leaves per plot. Disease severity (area infected) was rated using the Horsfall-Barratt scale and converted to percentages using Elanco's conversion tables. Means followed by the same letters within columns are not significantly different according to Tukey's Honest Significant Difference (HSD) Test ( $p \leq 0.05)$.

2 Inc. = Incidence; Sev. = Severity.

In 2018, the incidence of black rot (Table 3) was highest in 'Marquette' $(85.0 \%$ of fruit was affected) followed by 'Brianna' (73.3\%). 'Petite Pearl' had moderately high incidence (48.3\%), followed by 'Itasca' (30.0\%) and 'St. Pepin' (20.0\%). 'Louise Swenson' and 'Verona' had the lowest incidence of black rot on fruit (1.7 and 3.3\%) among all cultivars, and the severity followed a similar trend to the incidence in that year. The black rot incidence and severity were greater overall in 2019 , with all cultivars having incidence above $94 \%$, except 'Louise Swenson', for which $69.1 \%$ of the fruit was affected. There was a greater range in the severity of black rot damage among cultivars: 'Marechal Foch' had the most severe black rot on fruit, followed by 'Verona' and 'St. Pepin'. 'Crimson Pearl', 'Louise Swenson', and 'Petite Pearl' had the lowest severity of the disease on fruit in that year.

Although no symptoms of the disease were observed on foliage of 'Marechal Foch' and 'Petite Pearl' in 2018, Phomopsis incidence (Table 5) was observed for 1.7\% and 3.3\% of the fruit on those cultivars, respectively. No other cultivars had incidence of the disease that year, and this low overall incidence across all cultivars did not generate statistically significant differences. In 2019, 'Petite Pearl' was the only cultivar with Phomopsis symptoms on fruit, and $16.7 \%$ of the fruit were affected by the disease and severity was $0.4 \%$ of area affected. Botrytis bunch rot (Table 5) was relatively low in 2018 with no significant differences observed at $\alpha=0.05$. Of the nine cultivars evaluated in that year, 'Brianna', 'Crimson Pearl', 'Marquette', and 'Petite Pearl' had an incidence from 1.7-6.7\%, but the severity was well below 1\% of the fruit surface affected. In 2019, Botrytis bunch rot affected $51.7 \%$ of the assessed 'Marechal Foch' fruit; for all other cultivars, less than $11.7 \%$ of the fruit was affected. Severity was greatest on 'Marechal Foch', with $1.6 \%$ of the surface affected, and a damaged cluster area below $1 \%$ for the remaining cultivars.

Table 5. Comparison of the incidence percentage and severity of Phomopsis fruit rot and Botrytis bunch rot symptoms on grape fruit clusters in 2018 and 2019.

\begin{tabular}{|c|c|c|c|c|c|c|c|c|c|c|c|c|}
\hline \multirow{3}{*}{ Cultivars } & \multicolumn{6}{|c|}{ Phomopsis Fruit Rot ${ }^{1}$} & \multicolumn{6}{|c|}{ Botrytis Bunch Rot ${ }^{1}$} \\
\hline & \multicolumn{2}{|c|}{2018} & \multicolumn{4}{|c|}{2019} & \multicolumn{2}{|c|}{2018} & \multicolumn{4}{|c|}{2019} \\
\hline & $\%$ Inc. $^{2}$ & $\%$ Sev. $^{2}$ & \multicolumn{2}{|c|}{$\%$ Inc. } & \multicolumn{2}{|c|}{ \% Sev. } & \multirow{2}{*}{$\begin{array}{c}\% \text { Inc. } \\
6.67\end{array}$} & \multirow{2}{*}{$\begin{array}{c}\text { \% Sev. } \\
0.16\end{array}$} & \multicolumn{2}{|c|}{$\%$ Inc. } & \multicolumn{2}{|c|}{ \% Sev. } \\
\hline Brianna & 0.00 & 0.00 & 0.00 & $\mathrm{~b}$ & 0.00 & $\mathrm{~b}$ & & & 0.00 & $\mathrm{~b}$ & 0.00 & $\mathrm{~b}$ \\
\hline C. Pearl & 0.00 & 0.00 & 0.00 & $\mathrm{~b}$ & 0.00 & $\mathrm{~b}$ & 1.67 & 0.04 & 0.00 & $\mathrm{~b}$ & 0.00 & $\mathrm{~b}$ \\
\hline
\end{tabular}


Table 5. Cont.

\begin{tabular}{|c|c|c|c|c|c|c|c|c|c|c|c|c|}
\hline \multirow{4}{*}{$\begin{array}{c}\text { Cultivars } \\
\text { Marechal Foch }\end{array}$} & \multicolumn{6}{|c|}{ Phomopsis Fruit Rot ${ }^{1}$} & \multicolumn{6}{|c|}{ Botrytis Bunch Rot ${ }^{1}$} \\
\hline & \multicolumn{2}{|c|}{2018} & \multicolumn{4}{|c|}{2019} & \multicolumn{2}{|c|}{2018} & \multicolumn{4}{|c|}{2019} \\
\hline & \multirow{2}{*}{$\begin{array}{c}\text { \% }^{\text {Inc. }}{ }^{2} \\
1.67\end{array}$} & \multirow{2}{*}{$\begin{array}{c}\text { \% Sev. }^{2} \\
0.04\end{array}$} & \multicolumn{2}{|c|}{$\%$ Inc. } & \multicolumn{2}{|c|}{$\%$ Sev. } & \multirow{2}{*}{$\begin{array}{c}\text { \% Inc. } \\
0.00\end{array}$} & \multirow{2}{*}{$\begin{array}{c}\text { \% Sev. } \\
0.00\end{array}$} & \multicolumn{2}{|c|}{$\%$ Inc. } & \multicolumn{2}{|c|}{$\%$ Sev. } \\
\hline & & & 0.00 & $\mathrm{~b}$ & 0.00 & $\mathrm{~b}$ & & & 51.67 & $\mathrm{a}$ & 1.60 & a \\
\hline Itasca & 0.00 & 0.00 & 0.00 & $\mathrm{~b}$ & 0.00 & $\mathrm{~b}$ & 0.00 & 0.00 & 5.00 & $\mathrm{~b}$ & 0.12 & $\mathrm{~b}$ \\
\hline L. Swenson & 0.00 & 0.00 & 0.00 & $\mathrm{~b}$ & 0.00 & $\mathrm{~b}$ & 0.00 & 0.00 & 0.00 & $\mathrm{~b}$ & 0.00 & $\mathrm{~b}$ \\
\hline Marquette & 0.00 & 0.00 & - & & - & & 5.00 & 0.12 & - & & - & \\
\hline Petite Pearl & 3.33 & 0.08 & 16.67 & a & 0.39 & $\mathrm{a}$ & 1.67 & 0.04 & 1.67 & $\mathrm{~b}$ & 0.04 & $\mathrm{~b}$ \\
\hline St. Pepin & 0.00 & 0.00 & 0.00 & $\mathrm{~b}$ & 0.00 & $\mathrm{~b}$ & 0.00 & 0.00 & 11.67 & $b$ & 0.27 & $\mathrm{~b}$ \\
\hline Verona & 0.00 & 0.00 & 0.00 & $\mathrm{~b}$ & 0.00 & $\mathrm{~b}$ & 0.00 & 0.00 & 6.67 & $\mathrm{~b}$ & 0.16 & $\mathrm{~b}$ \\
\hline
\end{tabular}

${ }^{1}$ Values represent the mean from six replicate two-vine plots per cultivar of disease incidence on 10 fruit clusters per plot. Disease severity (area infected) was rated using the Horsfall-Barratt scale and converted to percentages using Elanco's conversion tables. Means followed by the same letters within columns are not significantly different according to Tukey's Honest Significant Difference (HSD) Test $(p \leq 0.05)$.

2 Inc. = Incidence; Sev. = Severity.

\section{Discussion}

Fungal diseases are often a limiting factor in grape production in the humid northeastern U.S.A. and were variable between the years of this study. Overall, we observed that disease incidence on foliage and fruit clusters was lower in 2018 compared with 2019, which was likely a result of the drier weather in the growing season (May through September) of 2018, which had a combined $31.95 \mathrm{~cm}$ rainfall compared with $43.36 \mathrm{~cm}$ recorded for the same months in the research plots in 2019 (Table S2). Total hours of leaf wetness were also considerably lower in 2018 (534 h) compared with 2019 (1018 h).

It is rare that commercial grape producers would not apply fungicides, whether synthetic or organically-approved, to manage diseases in their vineyards. However, information on the relative susceptibility of cultivars to disease is critical to developing IPM programs that reduce unneeded pesticide applications overall. Many grape cultivars also exhibit phytotoxic symptoms to copper and/or sulfur products, which are the most commonly used fungicides in organic production systems [23,24]. Furthermore, because most materials that are suitable for use in organic production systems are less effective and often may require more applications than synthetic materials while also delivering less effective results, selection of resistant cultivars is critical to success when adopting such a management program.

At the time of this writing, there were no reports on disease susceptibility found in the literature for the cultivars 'Crimson Pearl' and 'Verona', which are both relatively new releases from a private breeding program. 'Petite Pearl', which was also recently released from that program, has had limited disease evaluation conducted and reports collated in a recent literature review were generated primarily from Extension and observational reports [25]. 'Itasca', the next-most recently released cultivar (2017), was featured in a HortScience article upon its release, where relative resistance to powdery mildew was reported [26]. Of the remaining cultivars, several have been available for planting and testing for 12 to 70 years (Table 1), and thus, they have had varying levels of rigorous disease susceptibility assessment completed. Among the older cultivars in this trial, 'Marquette' has been evaluated in Vermont as part of a prior trial $[19,27]$. Finally, the Swenson-bred cultivars 'Brianna', 'Louise Swenson', and 'St. Pepin' have been included in a number of comparison studies that included vine growth and juice quality considerations, but little comprehensive disease evaluation has been conducted on any of them.

Among the significant disease reported on these cultivars, black rot is the primary disease affecting fruit in the northeastern U.S.A. and neighboring Canada, with powdery mildew following close behind. Powdery mildew is relatively easily managed by use of sulfur-based fungicides [18,23], but black rot in not easily managed with sulfur or copper materials used in organic production systems. Black rot is one of the most serious diseases of grapes in the eastern United States and can cause substantial crop loss under conducive weather conditions. Disease severity and inoculum from the previous year, 
current weather conditions, and varietal susceptibility all play a role in the impact and losses due to the disease. Managing inoculum and choosing the most black rot-resistant cultivars are important priorities for growers and often result in cost savings by decreasing the number of fungicide sprays necessary to manage a disease that occurs to some extent every season.

Phomopsis cane and leaf spot, while less potentially damaging than black rot, is another common disease of grapes in cold climate regions in the Northeastern U.S.A. [14], and the authors have observed near-total crop loss on unmanaged vines from the disease (unpublished data). Phomopsis incidence in 2012 was as high as 51.7\% on fruit clusters of 'Frontenac' in a previous evaluation of disease susceptibility on eight cultivars located at the same site [27]. Those older vines remain immediately adjacent to those in this present study, and are presently minimally-managed. Phomopsis inoculum primarily builds up and overwinters on older wood, e.g., cordons, trunks, and spurs, and it is likely that the young vines in the present study did not carry sufficient inoculum to cause infection. We expect that non-sprayed vines consisting of older tissues would lead to eventual buildup of the disease in the vineyard, but for this study, Phomopsis was absent during the two years of evaluation.

Powdery mildew is an important disease of grapes worldwide. Because the disease only requires high humidity, as opposed to leaf wetness, infection of powdery mildew may be a problem in dry but humid years when other diseases are less present [20]. Therefore, powdery mildew management may involve a different fungicide program than one which targets black rot, Phomopsis, and other diseases that proliferate in wet conditions [18]. Sulfur is a widely-used, inexpensive fungicide that is acceptable for use in organic production systems, and has excellent efficacy against this disease [23]. However, many grape cultivars are sensitive to sulfur and may exhibit phytotoxic responses to its application, which can be severe in some cases [24]. Of the cultivars rated in this study, 'Brianna' and 'Marechal Foch' have shown substantial phytotoxicity resulting from sulfur applications, whereas 'Marquette' and 'Petite Pearl' have not shown significant sulfur injury in previous research [24]. In Cadle-Davidson et al.'s review of Vitis species' susceptibility to powdery mildew in New York, which has a similar climate to Vermont, 'Marechal Foch' exhibited moderate to high susceptibility to the disease [28]. Importantly, $V$. vinifera selections showed greater susceptibility to powdery mildew than $V$. labrusca or $V$. riparia overall, which suggests that resistance may be greater in cultivars which include those species in their parentage. While incidence of powdery mildew in this study was relatively high on untreated vines, severity varied substantially, both by year and by cultivar. By developing an understanding of both the susceptibility of untreated cultivars to powdery mildew as well as the potential damage caused by sulfur application, a producer may make sound decisions on cultivar selection and development of organic or other pest management systems to minimize both disease and abiotic damage resulting from powdery mildew management.

Downy mildew can be a devastating disease that can completely and prematurely defoliate affected vineyards, thus lowering fruit quality, vine growth, and cold hardiness. This disease is native to eastern North America, and thus, interspecific hybrids including those in this study that have parentage including V. riparia and V. labrusca, which co-evolved with the pathogen Plasmopara viticola, tend to exhibit resistance to the disease [16,29]. This was observed in previous work that included these cultivars $[5,7,9,12,30]$, and this study supported those prior findings, as no downy mildew was observed on any of the cultivars. Absence of downy mildew in this trial was despite presence confirmed in and older adjacent vineyard and on wild grapes located within $50 \mathrm{~m}$ of the study location.

Anthracnose has become an increasingly common disease of grapes grown in Vermont. Work by Carisse and Lefebvre just to the north of this study site in Quebec, Canada surveyed a number of cold-hardy cultivars, including 'Louise Swenson', 'Marquette', and 'St. Pepin' which are in this study, for susceptibility to that disease [31]. In that work, most evaluated cultivars were rated as "resistant to slightly susceptible", with 'Louise Swenson' 
rated as "susceptible" and 'Marquette' exhibiting the highest severity of anthracnose among all tested cultivars and rated as "highly susceptible". Anthracnose incidence on leaves was low overall in this study, even on 'Marquette', and no affected fruit were observed on any cultivar. That may be attributed to low inoculum or to weather conditions during the study period, which were not conducive to disease development.

The grape and wine industry in Vermont and similar cold-climate regions in midwestern and eastern North America is relatively new, in many cases in existence less than 20 or 30 years [32]. The cultivars grown in the region are a changing mix of selections that may have been evaluated regionally or in more established production areas. Oftentimes, this mix includes both older selections that have been evaluated through research and on farms and newly released cultivars from breeding programs [1]. In many cases, materials that offer recommendations or ratings for cultivar disease susceptibility and other important characteristics are based on anecdotal or general observations and sometimes limited replicated field trials [25,33-35]. The collective, co-created knowledge generated from formal and informal research and farming networks can be highly useful in developing planting systems and management programs for a disease-susceptible, perennial crop with a high investment cost and long period of return, but quantitative and replicated research and validation of prior observations are critical to successful crop production.

Wines are produced from fruit, and disease-affected fruit may be completely unusable for wine production, whereas foliar disease may be present in a vineyard, and, depending on type and severity, a marketable crop can still be produced. After cold hardiness and acceptability for winemaking, susceptibility to common fruit diseases may be the most important criteria for selection of a suitable cultivar. In this study, cluster disease severity was variable among cultivars in each year, and not consistent over the course of the twoyears. All cultivars showed some level of powdery mildew and black rot in fruit clusters on non-treated vines in both years, and relative susceptibility to those two diseases may be key determinants in cultivar selection. However, no single cultivar was consistently more resistant to all the foliar or cluster diseases in this study and the ranking of cultivar susceptibility varied depending on the growing season and the disease. It is important to note that all cultivars had powdery mildew and black rot infections on fruit in both years.

\section{Conclusions}

This study has shown that the disease incidence ratings vary among cultivars and that disease ratings of cultivars are not always consistent in a two-year project. It is critical to increase the length of time for this type of study to track trends in disease incidence and severity over several years. In addition to increasing the number of years for these studies, yield data should be incorporated in future research, giving growers additional critical data to select the most productive disease-resistant cold hardy grape cultivars.

Supplementary Materials: The following are available online at https://www.mdpi.com/article/ 10.3390/horticulturae7080216/s1, Table S1. Horsfall-Barratt disease range used for data collection; Table S2. Weather conditions during the growing season.

Author Contributions: Conceptualization, T.L.B. and A.L.H.; methodology, T.L.B. and A.L.H.; validation, T.L.B.; formal analysis, G.S.M.; investigation, A.L.H. and G.S.M.; data curation, A.L.H. and G.S.M.; writing—original draft preparation, T.L.B. and A.L.H.; writing—review and editing, T.L.B. and A.L.H.; visualization, G.S.M.; supervision, T.L.B. and A.L.H.; project administration, T.L.B.; funding acquisition, T.L.B. and A.L.H. All authors have read and agreed to the published version of the manuscript.

Funding: This research was funded by the Crop Protection and Pest Management Program, grant no. 2017-70006-27143/1013802 from the USDA National Institute of Food and Agriculture, Vermont Specialty Crops Block Grants Program grant number 02200-SCBGP-13-4 and Vermont Agriculture Experiment Station Hatch Project "Evaluating systems components for orchard and vineyard crops in Vermont". The work is part of USDA NE1720: Multi-state Coordinated Evaluation of Winegrape Cultivars and Clones project. Any opinions, findings, conclusions, or recommendations expressed 
in this publication are those of the author(s) and do not necessarily reflect the view of the U.S. Department of Agriculture or Vermont Department of Agriculture, Food, and Markets.

Data Availability Statement: Data files and SAS code are available at: http://www.uvm.edu/ tbradsha/2107HortFiles/.

Acknowledgments: The authors with to thank Joan Skelly, Sarah Kingsley-Richards, and Jessica Foster for their invaluable assistance with this project.

Conflicts of Interest: The authors declare no conflict of interest. The funders had no role in the design of the study; in the collection, analyses, or interpretation of data; in the writing of the manuscript, or in the decision to publish the results.

\section{References}

1. Bradshaw, T.L.; Hazelrigg, A.; Berkett, L.P. Characteristics of the cold-climate winegrape industry in Vermont, U.S.A. Acta Hort. 2018, 1205, 469-476. [CrossRef]

2. NASS. Annual Bulletin, New England Agricultural Statistics. 2014. Available online: http://www.nass.usda.gov/Statistics_by_ State/New_England_includes/Publications /Annual_Statistical_Bulletin/2014\%20New\%20England\%20Annual\%20Bulletin. pdf (accessed on 31 May 2021).

3. USDA National Agricultural Statistics Services. 2012 Census of Agriculture. Available online: https://www.nass.usda.gov/ Publications/AgCensus/2012/index.php (accessed on 29 July 2021).

4. USDA National Agricultural Statistics Services. 2017 Census of Agriculture. Available online: https://www.nass.usda.gov/ Publications / AgCensus / 2017/index.php (accessed on 29 July 2021).

5. Cannella, M.P. 2015 Vermont Vineyard Feasibility Study; University of Vermont Extension: Burlington, VT, USA, 2015 ; FBRR 014. Available online: https:/ / blog.uvm.edu/farmvia/files/2013/03/FBRR014-2015-VineyardFeasibilityStudy.pdf (accessed on 29 July 2021).

6. Holiman, E.C. The Vermont Wine Industry: The Emergence of Cold Climate Viticulture and The Uncertain Future in the Face of Climate Change. Bachelor's Honors Thesis, University of Vermont, Burlington, VT, USA, 2020.

7. Nonnecke, G.; Domoto, P.; Cochran, D. NE-1020 Cold Hardy Wine Grape Cultivar Trial; Iowa State Research Farm Progress Reports 2173; Iowa State University: Ames, IA, USA, 2015. Available online: http://lib.dr.iastate.edu/farms_reports/2173. (accessed on 29 July 2021).

8. Read, P.E.; Gamet, S.J. Sixteen years of cold-climate cultivar evaluation. Acta Hort. 2016, 23-28. [CrossRef]

9. Bradshaw, T.L.; Berkett, L.P.; Kingsley-Richards, S.L.; Foster, J.A. Horticultural Performance and Juice Quality of Cold-Climate Grapes in Vermont, U.S.A. Eur. J. Hortic. Sci. 2017, 83, 42-48. [CrossRef]

10. Hatterman-Valenti, H.M.; Auwarter, C.P.; Stenger, J.E. Evaluation of cold-hardy grape cultivars for North Dakota and the North Dakota State University germplasm enhancement project. Acta Hort. 2016, 1115, 13-22. [CrossRef]

11. NERA. NE1720: Multi-state Coordinated Evaluation of Winegrape Cultivars and Clones. Available online: https://www.nimss. org/projects/18405 (accessed on 31 May 2021).

12. Martinson, T.E.; Mansfield, A.K.; Luby, J.J.; Gartner, W.C.; Dharmadhikari, M.; Domoto, P. The Northern Grapes Project: Integrating viticulture, enology, and marketing of new cold-hardy wine grape cultivars in the Midwest and Northeast United States. Acta Hort. 2016, 1115, 3-12. [CrossRef]

13. Cattell, H. Wines of Eastern North America; Cornell University Press: Ithaca, NY, USA, 2014.

14. Hazelrigg, A.; Kingsley-Richards, S. Pest Management Strategic Plan for Grapes in the Northeast; Northeast IPM Center: Ithaca, NY, USA, 2017. Available online: https://ipmdata.ipmcenters.org/documents/pmsps/Grape-PMSP-for-Northeast-2017.pdf. (accessed on 29 July 2021).

15. Hemstad, P.; Breeder, G. Grapevine breeding in the Midwest. In Grapevine Breeding Programs for the Wine Industry: Traditional and Molecular Techniques; Reynolds, A., Ed.; Woodhead Publishing: Cambridge, UK, 2015; pp. 411-425.

16. Swenson, E.P. Wild Vitis Riparia from northern US and Canada-breeding source for winter hardiness in cultivated grapes-a background of the Swenson hybrids. Fruit Var. J. 1985, 39, 28-31. Available online: https://www.pubhort.org/aps/39/v39_n1 _a10.htm (accessed on 29 July 2021).

17. Bradshaw, T.; Berkett, L. An Initial IPM Strategy for New Cold Climate Winegrape Growers; UVMFRT004; University of Vermont Extension: Burlington, VT, USA, 2017. Available online: https://www.uvm.edu/ \{\}orchard/fruit/pubs/Factsheets/UVMFRT0 04_initialIPMStrategy.pdf (accessed on 29 July 2021).

18. Weigle, T.; Muza, A. (Eds.) New York and Pennsylvania Pest Management Guidelines for Grapes; Cornell University: Ithaca, NY, USA, 2016.

19. Hazelrigg, A.; Bradshaw, T.L.; Berkett, L.P.; Maia, G.; Kingsley-Richards, S.L. Disease Susceptibility of Cold-Climate Grapes in Vermont, U.S.A. Acta Hort. 2018, 1205, 477-482. [CrossRef]

20. Wilcox, W.F.; Gubler, W.D.; Uyemoto, J.K. Compendium of Grape Diseases, Disorders, and Pests; APS Press, The American Phytopathological Society: St. Paul, MN, USA, 2015. 
21. Jones, D.S.; McManus, P.S. Distinctive Symptoms and Signs of Downy Mildew on Cold-Climate Wine Grape Cultivars. Plant Health Prog. 2017, 18, 192-195. [CrossRef]

22. Horsfall, J.G.; Barratt, R.W. An improved grading system for measuring plant diseases. Phytopathology 1945, 35, 655.

23. Weigle, T.; Carroll, J. (Eds.) Organic Production and IPM Guide for Grapes; NYS IPM: Geneva, NY, USA, 2016 ; Volume 224.

24. McManus, P.S.; Kartanos, V.; Stasiak, M. Sensitivity of cold-climate wine grape cultivars to copper, sulfur, and difenoconazole fungicides. Crop. Prot. 2017, 92, 122-130. [CrossRef]

25. Pedneault, K.; Provost, C. Fungus resistant grape varieties as a suitable alternative for organic wine production: Benefits, limits, and challenges. Sci. Hortic. 2016, 208, 57-77. [CrossRef]

26. Clark, M.; Hemstad, P.; Luby, J. 'Itasca' Grapevine, a New Cold-hardy Hybrid for White Wine Production. HortScience 2017, 52, 649-651. [CrossRef]

27. Berkett, L.; Bradshaw, T.; Kingsley-Richards, S.; Griffith, M. Disease Evaluation of Selected Cold Climate Wine Grape Cultivars in Vermont, USA; International Organisation for Biological Control: Zürich, Switzerland, 2014; Volume 105, pp. 29-33.

28. Cadle-Davidson, L.; Chicoine, D.R.; Consolie, N.H. Variation within and among Vitis spp. for foliar resistance to the powdery mildew pathogen Erysiphe necator. Plant Dis. 2011, 95, 202-211. [CrossRef] [PubMed]

29. Hemstad, P.; Luby, J. Utilization of Vitis riparia for the development of new wine varieties with resistance to disease and extreme cold. Acta Hort. 2000, 528, 487-496. [CrossRef]

30. Jones, D.S.; McManus, P.S. Susceptibility of cold-climate wine grape cultivars to downy mildew, powdery mildew, and black rot. Plant Dis. 2017, 101, 1077-1085. [CrossRef] [PubMed]

31. Carisse, O.; Lefebvre, A. Evaluation of northern grape hybrid cultivars for their susceptibility to anthracnose caused by Elsinoe ampelina. Plant Health Prog. 2011, 12, 9. [CrossRef]

32. Trzaskos, T. Wines of Vermont: A History of Pioneer Fermentation; The History Press: Mount Pleasant, SC, USA, 2015.

33. Delate, K.; Friedrich, H. Organic apple and grape performance in the Midwestern US. Acta Hort. Iculturae 2004, 638, 309-320. [CrossRef]

34. Bradshaw, T.L.; Hazelrigg, A.; Berkett, L. Relative Disease Ratings for Wine Grape Varieties Grown in Vermont; UVMFRT003; UVM Extension: Burlington, VT, USA, 2020. Available online: https://www.uvm.edu/ \{\}orchard/fruit/pubs/Factsheets/UVMFRT0 03_relativeGrapeDisease.pdf (accessed on 29 July 2021).

35. Reisch, B.; Pool, R.; Peterson, D.; Martens, M.-H.; Henick-Kling, T. Wine and Juice Grape Varieties for Cool Climates; Information Bulletin 233; NYSAES: Geneva, NY, USA, 1993. Available online: https:/ / hdl.handle.net/1813/17814 (accessed on 29 July 2021). 